\title{
Crystal-Engineering Studies of Coordination Polymers and a Molecular-Looped Complex Containing Dipyridyl-Amide Ligands
}

\author{
Biing-Chiau Tzeng, ${ }^{*, \dagger}$ Yung-Chi Huang, ${ }^{\dagger}$ Bo-So Chen, ${ }^{\dagger}$ Wan-Min Wu, ${ }^{\dagger}$ Shih-Yang Lee, ${ }^{\dagger}$ \\ Gene-Hsiang Lee, ${ }^{\ddagger}$ and Shie-Ming Peng ${ }^{\ddagger}$ \\ Department of Chemistry and Biochemistry, National Chung Cheng University, \\ 168 University Road, Min-Hsiung, Chia-Yi, Taiwan 621, and Department of Chemistry, \\ National Taiwan University, 1, Sec. 4, Roosevelt Road, Taipei, Taiwan 106 \\ Received August 12, 2006
}

\begin{abstract}
We report herein crystal-engineering studies of coordination polymers and a molecular-looped complex containing two dipyridyl-amide ligands, 1,3-bis-pyridin-4-ylmethyl urea (L1) and N,N'-bis-4-methylpyridyl oxalamide (L2). The reaction of $\mathrm{Cd}(\mathrm{OAc})_{2}$ with $\mathrm{L} 1$ gives rise to $\left[\mathrm{Cd}(\mathrm{OAc})_{2}(\mathrm{~L} 1)\right]_{n}(1)$, a 1-D chain through coordination to two $\mathrm{L} 1$ and two acetate ligands, and then the axial coordination to one urea's carbonyl group through the third L1 ligand leads 1 to form "a dimer of 1-D chains". With a slight change in the structural backbone from L1 to L2, the reaction of L2 with $\mathrm{Cd}(\mathrm{OAc})_{2}$ gives $\left[\mathrm{Cd}(\mathrm{OAc})_{2}(\mathrm{L2})\left(\mathrm{H}_{2} \mathrm{O}\right)\right]_{n}(2)$, a 1-D chain structure. The reaction of $\mathrm{Cd}\left(\mathrm{NO}_{3}\right)_{2}$, instead of $\mathrm{Cd}$ $(\mathrm{OAc})_{2}$, with $\mathbf{L} 2$ gives $\left[\mathrm{Cd}\left(\mathrm{NO}_{3}\right)_{2}(\mathrm{~L} 2)_{3 / 2}\right]_{n}(3)$, where the coordinated-anion effect on the assembly process has been observed for 2 and 3 . The former forms a 1-D chain structure, and the latter, a 2-D sheet structure, depending on the coordinated anions used. $\left[\mathrm{HgCl}_{2}(\mathbf{L} 1)\right]_{n}(\mathbf{4})$ and $\left[\mathrm{CuCl}_{2}(\mathbf{L} 2)\right]_{n}(\mathbf{5})$, which are 1-D chain structures, show tetrahedral $[\mathrm{Hg}(\mathrm{II})]$ and square-planar $[\mathrm{Cu}(\mathrm{II})]$ centers, respectively. Surprisingly, 4 shows a typical amide-amide hydrogen bonding and $\mathbf{5}$ shows none. Instead, a hydrogen-bonding interaction between $\mathrm{Cl}$ and the amide group is observed in 5. Finally, the different structural conformation of $\mathbf{L} 2$ (a syn or anti form) leads to the formation of different structural motifs, coordination polymers (2, 3, and $\mathbf{5}$ with an anti form), and a macrocycle ( $[\mathrm{Pd}(\mathrm{PPy})(\mathbf{L} 2)]_{2}\left(\mathrm{ClO}_{4}\right)_{2}(\mathbf{6})$ with a syn form, PPy = 2-phenylpyridine). Each side of the boat form of 6 (pseudo-cyclohexane) ranges from 6.12 to $6.39 \AA$, and the molecular loop is further hydrogen-bonded to stack into a 1-D hydrogen-bonded framework with a ladder pattern through amide-amide hydrogen bonding. Interestingly, one $\mathrm{ClO}_{4}^{-}$anion is encapsulated inside the cavity through multiple $\mathrm{CH} \cdots \mathrm{O}$ interactions.
\end{abstract}

\section{Introduction}

The coordinative-bond approach has been widely used in the construction of coordination polymers with a wide range of 1-, 2-, and 3-D infinite solid-state networks ${ }^{1}$ as well as discrete supramolecular entities. ${ }^{2}$ Moreover, it is also possible, in parallel, to use highly directional hydrogen bonds

\footnotetext{
* To whom correspondence should be addressed. E-mail: chebct@ccu.edu.tw.

National Chung Cheng University.

$\doteqdot$ National Taiwan University.

(1) (a) Janiak, C. Dalton Trans. 2003, 2781. (b) Yaghi, O. M.; Li, H.; Davis, C.; Richardson, D.; Groy, T. L. Acc. Chem. Res. 1998, 31, 474. (c) Swiegers, G. F.; Malefetse, T. J. Chem. Rev. 2000, 100, 3483. (d) Zaworotko, M. J. Angew. Chem., Int. Ed. 2000, 39, 3052. (e) Batten, S. R.; Robson, R. Angew. Chem., Int. Ed. 1998, 37, 1461. (f) Hagrman, P. J.; Hagrman, D.; Zubieta, J. Angew. Chem., Int. Ed. 1999, 38, 2639. (g) James, S. L. Chem. Soc. Rev. 2003, 32, 276. (h) Kitagawa, S.; Kitaura, R.; Noro, S.-I. Angew. Chem., Int. Ed. 2004, $43,2334$.
}

186 Inorganic Chemistry, Vol. 46, No. 1, 2007 as a means of controlling self assembly in supramolecular systems. In this context, the combination of the coordinativebond approach, hydrogen bonding, and/or other weak interactions (that is, $\pi^{\cdots *} \pi$ interactions) has recently been recognized as a very powerful and versatile strategy in material synthesis. ${ }^{3}$ A paradigm example of a supramolecular system, [(en)Pd(4,4'-bpy) $]_{4}\left(\mathrm{NO}_{3}\right)_{8}$ (en = ethylenediamine; $4,4^{\prime}$-bpy $=4,4^{\prime}$-bipyridyl), was first reported by Fujita et

(2) (a) Fujita, M. Chem. Soc. Rev. 1998, 27, 417. (b) Leininger, S. Olenyuk, B.; Stang, P. J. Chem. Rev. 2000, 100, 853. (c) Holliday, B. J.; Mirkin, C. A. Angew. Chem., Int. Ed. 2001, 40, 2022. (d) Dinolfom, P. H.; Hupp, J. T. Chem. Mater. 2001, 13, 3113. (e) Seidel, S. R.; Stang, P. J. Acc. Chem. Res. 2002, 35, 972. (f) Fujita, M.; Tominaga, M.; Hori, A.; Therrien, B. Acc. Chem. Res. 2005, 38, 371. (g) Thanasekaran, P.; Liao, R.-T.; Liu, Y.-H.; Rajendran, T.; Rajagopal, S.; Lu, K.-L. Coord. Chem. Rev. 2005, 249, 1085. (h) Atwood, J. L.; Barbour, L. J. Cryst. Growth Des. 2003, 3, 3. (i) Cotton, F. A.; Lin, C.; Murillo, C. A. Acc. Chem. Res. 2001, 34, 759. (j) Steel, P. J. Acc. Chem. Res. 2005, 38, 243.

10.1021/ic061528t CCC: $\$ 37.00$ @ 2007 American Chemical Society Published on Web 12/07/2006 
al., ${ }^{4 a}$ and its molecular structure was further determined by an X-ray diffraction study confirming a molecular-square structure..$^{4 \mathrm{~b}}$ Later, $\left[\mathrm{Re}(\mathrm{CO})_{3} \mathrm{X} \text { (diimine) }\right]_{4}(\mathrm{X}=\mathrm{Cl}, \mathrm{Br}$; diimine $=$ pyrazine, 4,4-bipyridine, or other linear spacers), also reported by the Hupp group, was shown to represent another interesting family of neutral molecular squares with tunable cavity sizes, depending on the linear spacers used. ${ }^{5}$ The related studies have so far extended to molecular triangles, rectangles, pentagons, hexagons, cages, and so forth. ${ }^{2}$ Applications, including chemical sieving, sensing, and catalysis, based on these supramolecular systems have recently been found, and some have shown exciting results. ${ }^{6}$

Organic amides have long proved to be very useful in self assembly through hydrogen bonding, and the assembled products have relevance to biological systems. With reference to the delicate work reported by Ghadiri et al., ${ }^{7}$ cyclic oligoamides can be used as building units to give interesting nanotubes or zeolite-like frameworks through inter-ring and/ or inter-tube $\mathrm{NH} \cdots \mathrm{O}=\mathrm{C}$ hydrogen bonding, potentially representing a new family of functional materials. However, the related study based on metal-containing cyclic amides is still in its infancy. Puddephatt et al. reported an intriguing work based on this novel idea toward the construction of a metal-containing [Pt(II) ions] supramolecular structure with dipyridyl-amide ( $N$-pyridin-4-yl-isonicotinamide) as a bridging ligand and of $\mathrm{Pt}(\mathrm{II})$ ions as connectors in the assembly process. ${ }^{8}$ The complex cation appears to be an interesting example of a triangular structure that forms a dimeric architecture through the $\mathrm{NH} \cdots \mathrm{O}=\mathrm{C}$ hydrogen bonding and

(3) (a) Burrows, A. D.; Chan, C.-W.; Chowdhry, M. W.; McGrady, J. E.; Mingos, D. M. P. Chem. Soc. Rev. 1995, 24, 329. (b) Gianneschi, N. C.; Tiekink, E. R. T.; Rendina, L. M. J. Am. Chem. Soc. 2000, 122, 8474. (c) Burrows, A. D.; Mingos, D. M. P.; White, A. J. P.; Williams, D. J. Chem. Commun. 1996, 97. (d) Chen, Z.-N.; Zhang, H.-X.; Yu, K.-B.; Zheng, K.-C.; Cai, H.; Kang, B.-S. J. Chem. Soc., Dalton Trans. 1998, 1133. (e) Aakeröy, C. B.; Beatty, A. M.; Helfrich, B. A. J. Chem Soc., Dalton Trans. 1998, 1943. (f) Cameron, B. R.; Corrent, S. S.; Loeb, S. J. Angew. Chem., Int. Ed. 1995, 34, 2689. (g) Copp, S. B.; Subramanian, S.; Zaworotko, M. J. J. Am. Chem. Soc. 1992, 114, 8719 . (h) Qin, Z.; Jennings, M. C.; Puddephatt, R. J. Chem. Commun. 2002 , 354. (i) Muthu, S.; Yip, J. H. K.; Vittal, J. J. J. Chem. Soc., Dalton Trans. 2002, 4561. (j) Muthu, S.; Yip, J. H. K.; Vittal, J. J. J. Chem. Soc., Dalton Trans. 2001, 3577. (k) Burchell, T. J.; Eisler, D. J.; Puddephatt, R. J. Inorg. Chem. 2004, 43, 5550. (1) Schauer, C. L.; Matwey, E.; Fowler, F. W.; Lauher, J. W. Cryst. Eng. 1998, 1, 213.

(4) (a) Fujita, M.; Yazaki, J.; Ogura, K. J. Am. Chem. Soc. 1990, 112, 5645. (b) Fujita, M.; Sasaki, O.; Mitsuhashi, T.; Fujita, T.; Yazaki, J.; Yamaguchi, K.; Ogura, K. Chem. Commun. 1996, 1535.

(5) (a) Slone, R. V.; Hupp, J. T.; Stern, C. L.; Albrecht-Schmitt, T. E. Inorg. Chem. 1996, 35, 4096. (b) Slone, R. V.; Hupp, J. T. Inorg. Chem. 1997, 36, 5422.

(6) (a) Bélanger, S.; Hupp, J. T.; Stern, C. L.; Slone, R. V.; Watson, D. F.; Carrell, T. M. J. Am. Chem. Soc. 1999, 121, 557. (b) Bélanger, S.; Hupp, J. T. Angew. Chem., Int. Ed. 1999, 38, 2222. (c) Mines, G. A.; Tzeng, B.-C.; Stevenson, K. J.; Li, J.; Hupp, J. T. Angew. Chem., Int. Ed. 2002, 41, 154. (d) Keefe, M. H.; Slone, R. V.; Hupp, J. T.; Czaplewski, K. F.; Snurr, R. Q.; Stern, C. L. Langmuir 2000, 16, 3964. (e) Merlau, M. L.; Mejia, M. D. P.; Nguyen, S. T.; Hupp, J. T. Angew. Chem., Int. Ed. 2001, 40, 4239. (f) Tashiro, S.; Tominaga, M.; Kawano, M.; Therrien, B.; Ozeki, T.; Fujita, M. J. Am. Chem. Soc. 2005, 127, 4546. (g) Yoshizawa, M.; Takeyama, Y.; Okano, T.; Fujita, M. J. Am. Chem. Soc. 2003, 125, 3243.

(7) (a) Hartgerink, J. D.; Clark, T. D.; Ghadiri, M. R. Chem.-Eur. J. 1998, 4, 1367. (b) Ghadiri, M. R.; Kobayashi, K.; Granja, J. R.; Chadha, R. K.; McRee, D. E. Angew. Chem., Int. Ed. 1995, 34, 93.

(8) (a) Qin, Z.; Jennings, M. C.; Puddephatt, R. J. Chem. Commun. 2001, 2676. (b) Qin, Z.; Jennings, M. C.; Puddephatt, R. J. Inorg. Chem. 2003, 42, 1956.
$\mathrm{Pt} \cdots \mathrm{O}=\mathrm{C}$ interactions similar to that formed by cyclic peptides, and it suggests that the biomimetic approach to the organization of the coordination networks holds considerable promise.

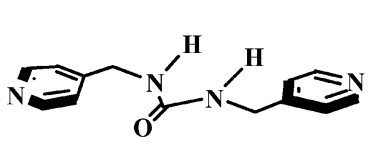

L1

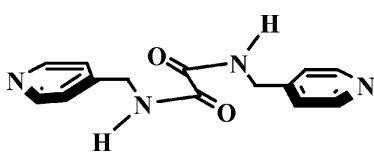

L2
$\mathrm{We}^{9}$ and other groups ${ }^{3 \mathrm{~h}-1}$ have previously constructed some interesting molecular rectangles, triangles, and coordination polymers and successfully demonstrated the important role of hydrogen-bonding interactions in the crystal-engineering study for the metal-containing pyridyl-amide system. Indeed, the previous work also confirms that the amide-amide hydrogen bonding did increase the supramolecular complexity in the solid state. We report herein the crystal-engineering study of coordination polymers and a molecular-looped complex containing two dipyridyl-amide ligands, 1,3-bispyridin-4-ylmethyl urea (L1) and $N, N^{\prime}$-bis-4-methylpyridyl oxalamide (L2).

\section{Experimental Section}

General Information. The reaction for $[\mathrm{Pd}(\mathrm{PPy})(\mathbf{L} 2)]_{2}\left(\mathrm{ClO}_{4}\right)_{2}$ (PPy $=2$-phenylpyridine) was performed under a nitrogen atmosphere, and the solvents for syntheses (analytical grade) were purified by literature methods. Caution: Perchlorate salts are potentially explosive and should be handled with care and in small amounts. NMR: Bruker DPX 400 MHz NMR; deuterated solvents with the usual standards. 1,3-Bis-pyridin-4-ylmethyl urea (L1) and $N, N^{\prime}$-bis-4-methylpyridyl oxalamide (L2) were prepared by literature methods, ${ }^{10}$ and $[\mathrm{Pd}(\mathrm{PPy})(\mathrm{OAc})]_{2}$ was also prepared in a modified method. ${ }^{11}$

Syntheses of $\left[\mathrm{Cd}(\mathrm{OAc})_{2} \mathrm{~L} 1\right]_{n}(1),\left[\mathrm{Cd}(\mathrm{OAc})_{2}(\mathrm{~L} 2)\left(\mathrm{H}_{2} \mathrm{O}\right)\right]_{n}(2)$, $\left[\mathrm{Cd}\left(\mathrm{NO}_{3}\right)_{2}(\mathrm{L2})_{3 / 2}\right]_{n}(3),\left[\mathrm{HgCl}_{2}(\mathrm{L1})\right]_{n}(4)$, and $\left[\mathrm{CuCl}_{2}(\mathrm{L2})\right]_{n}(5)$. 1: $\mathrm{Cd}(\mathrm{OAc})_{2} \cdot 2 \mathrm{H}_{2} \mathrm{O}(26 \mathrm{mg}, 0.1 \mathrm{mmol})$ dissolved in $7 \mathrm{~mL}$ of $\mathrm{C}_{2} \mathrm{H}_{5^{-}}$ $\mathrm{OH}$ was carefully layered onto a dimethylforamide (DMF) solution of $\mathbf{L 1}$ (24 $\mathrm{mg}(0.1 \mathrm{mmol})$, dissolved in $7 \mathrm{~mL}$ of DMF). The colorless crystals were obtained within 5 days in an $\sim 74 \%$ yield. FTIR $(\mathrm{KBr}): v_{\mathrm{NH}}=3267 \mathrm{~cm}^{-1}$ and $v_{\mathrm{C}=\mathrm{O}}=1651 \mathrm{~cm}^{-1}$. Anal. Calcd for $\mathrm{C}_{17} \mathrm{H}_{20} \mathrm{CdN}_{4} \mathrm{O}_{5}$ : C, 43.19; H, 4.26; N, 11.85. Found: C, 42.80; H, 4.26; $\mathrm{N}, 11.63 .2: \mathrm{Cd}(\mathrm{OAc})_{2} \cdot 2 \mathrm{H}_{2} \mathrm{O}(26 \mathrm{mg}, 0.1 \mathrm{mmol})$ dissolved in $7 \mathrm{~mL}$ of $\mathrm{CH}_{3} \mathrm{OH}$ was carefully layered onto a tetrahydrofuran (THF) solution of $\mathbf{L 2}(27 \mathrm{mg}(0.1 \mathrm{mmol})$, dissolved in $7 \mathrm{~mL}$ of THF). The colorless crystals were obtained within 2 weeks in an $\sim 56 \%$ yield. FTIR $(\mathrm{KBr}): v_{\mathrm{NH}}=3280 \mathrm{~cm}^{-1}$ and $v_{\mathrm{C}=\mathrm{O}}=1686$ $\mathrm{cm}^{-1}$. Anal. Calcd for $\mathrm{C}_{36} \mathrm{H}_{40} \mathrm{Cd}_{2} \mathrm{~N}_{8} \mathrm{O}_{14}: \mathrm{C}, 41.83 ; \mathrm{H}, 3.90 ; \mathrm{N}$, 10.84. Found: C, $41.67 ; \mathrm{H}, 4.27 ; \mathrm{N}, 10.80 .3: \mathrm{Cd}\left(\mathrm{NO}_{3}\right)_{2} \cdot 4 \mathrm{H}_{2} \mathrm{O}$ (26 mg, $0.1 \mathrm{mmol}$ ) dissolved in $7 \mathrm{~mL}$ of $\mathrm{CH}_{3} \mathrm{OH}$ was carefully layered onto a THF solution of $\mathbf{L} 2(27 \mathrm{mg}(0.1 \mathrm{mmol})$, dissolved in $7 \mathrm{~mL}$ of THF). The colorless crystals were obtained within 6

(9) (a) Tzeng, B.-C.; Chen, B.-S.; Lee, S.-Y.; Liu, W.-H.; Lee, G.-H.; Peng, S.-M. New J. Chem. 2005, 29, 1254-1257. (b) Tzeng, B.-C.; Yeh, H.-T.; Wu, Y.-L.; Kuo, J.-H.; Lee, G.-H.; Peng, S.-M. Inorg. Chem. 2006, 45, 591. (c) Tzeng, B.-C.; Lu, Y.-M.; Lee, G.-H.; Peng, S.-M. Eur. J. Inorg. Chem. 2006, 1698. (d) Tzeng, B.-C.; Chen, B.S.; Yeh, H.-T.; Lee, G.-H.; Peng, S.-M. New J. Chem. 2006, 30, 1087.

(10) Fraser, C. S. A.; Eisler, D. J.; Jennings, M. C.; Puddephatt, R. J. Chem. Commun. 2002, 1224.

(11) Constable, E. C.; Cargill Thompson, A. M. W.; Leese, T. A.; Reese, D. G. F.; Tocher, D. A. Inorg. Chim. Acta. 1991, 182, 93. 
Tzeng et al.

Table 1. Crystallographic Data of 1-6

\begin{tabular}{|c|c|c|c|c|c|c|}
\hline & 1 & 2 & 3 & 4 & $\mathbf{5} \cdot 2 \mathrm{CH}_{3} \mathrm{OH}$ & $\mathbf{6} \cdot 3 / 2 \mathrm{DMF} \cdot \mathrm{Et}_{2} \mathrm{O}$ \\
\hline $\begin{array}{l}\text { empirical } \\
\text { formula }\end{array}$ & $\mathrm{C}_{17} \mathrm{H}_{20} \mathrm{CdN}_{4} \mathrm{O}_{5}$ & $\mathrm{C}_{36} \mathrm{H}_{40} \mathrm{Cd}_{2} \mathrm{~N}_{8} \mathrm{O}_{14}$ & $\mathrm{C}_{21} \mathrm{H}_{21} \mathrm{CdN}_{8} \mathrm{O}_{9}$ & $\mathrm{C}_{6.5} \mathrm{H}_{7} \mathrm{ClHg}_{0.5} \mathrm{~N}_{2} \mathrm{O}_{0.5}$ & $\mathrm{C}_{16} \mathrm{H}_{22} \mathrm{Cl}_{2} \mathrm{CuN}_{4} \mathrm{O}_{4}$ & $\mathrm{C}_{58.5} \mathrm{H}_{64.5} \mathrm{Cl}_{2} \mathrm{~N}_{11.5} \mathrm{O}_{14.5} \mathrm{Pd}_{2}$ \\
\hline & 472.77 & 1033.56 & 641.86 & 256.89 & 468.82 & 1444.42 \\
\hline cryst sys & monoclinic & monoclinic & monoclinic & monoclinic & monoclinic & triclinic \\
\hline $\begin{array}{l}\text { space group } \\
\text { (no.) }\end{array}$ & $P n$ & $C 2 / c$ & $P 2_{1} / c$ & $P 2 / n$ & $C 2 / c$ & $P \overline{1}$ \\
\hline$a(\AA)$ & $9.393(2)$ & $16.245(2)$ & $10.929(3)$ & $14.609(1)$ & $17.559(1)$ & $10.0358(1)$ \\
\hline$b(\AA)$ & $8.962(2)$ & $15.472(1)$ & $11.975(3)$ & $4.471(1)$ & $8.041(1)$ & $17.9641(2)$ \\
\hline$c(\AA)$ & $11.080(2)$ & $8.834(1)$ & $19.959(5)$ & $15.142(1)$ & $15.914(1)$ & $19.8571(3)$ \\
\hline$\alpha(\mathrm{deg})$ & & & & & & $63.1720(7)$ \\
\hline$\beta(\mathrm{deg})$ & $95.567(3)$ & $98.718(2)$ & $105.827(5)$ & $106.779(2)$ & $118.900(2)$ & $85.0680(7)$ \\
\hline$\gamma(\mathrm{deg})$ & & & & & & $76.8756(6)$ \\
\hline$V\left(\AA^{3}\right)$ & $928.3(3)$ & 2194.5(3) & 2513.1(11) & $946.9(2)$ & $1967.0(1)$ & $3110.59(7)$ \\
\hline$Z$ & 2 & 2 & 4 & 4 & 4 & 2 \\
\hline$F(000)(\mathrm{e})$ & 476 & 1040 & 1292 & 484 & 964 & 1476 \\
\hline $\begin{array}{c}\mu(\mathrm{Mo} \mathrm{K \alpha}) \\
\left(\mathrm{mm}^{-1}\right)\end{array}$ & 1.213 & 1.040 & 0.937 & 8.412 & 1.412 & 0.738 \\
\hline$T(\mathrm{~K})$ & $273(2)$ & $273(2)$ & $273(2)$ & $273(2)$ & $150(1)$ & $150(1)$ \\
\hline reflns collected & 5542 & 9611 & 29068 & 5452 & 10567 & 49928 \\
\hline $\begin{array}{l}\text { independent } \\
\text { reflns }\end{array}$ & $\begin{array}{l}2655 \\
\quad\left(R_{\mathrm{int}}=0.028\right)\end{array}$ & $\begin{array}{l}2640 \\
\quad\left(R_{\text {int }}=0.030\right)\end{array}$ & $\begin{array}{l}6072 \\
\quad\left(R_{\mathrm{int}}=0.092\right)\end{array}$ & $\begin{array}{l}2220 \\
\quad\left(R_{\text {int }}=0.019\right)\end{array}$ & $\begin{array}{l}1737 \\
\quad\left(R_{\text {int }}=0.111\right)\end{array}$ & $\begin{array}{l}14190 \\
\quad\left(R_{\text {int }}=0.059\right)\end{array}$ \\
\hline $\begin{array}{l}\text { observed reflns } \\
\qquad\left(F_{\mathrm{o}} \geq 2 \sigma\left(F_{\mathrm{o}}\right)\right)\end{array}$ & 2655 & 2640 & 6072 & 2220 & 1737 & 14190 \\
\hline $\begin{array}{l}\text { refined } \\
\text { params }\end{array}$ & 246 & 138 & 352 & 102 & 129 & 740 \\
\hline GOF on $F^{2}$ & 0.991 & 1.095 & 1.025 & 1.137 & 1.116 & 1.013 \\
\hline $\begin{array}{l}R^{a}, R_{\mathrm{w}}^{b} \\
\quad(I \geq 2 \sigma(I))\end{array}$ & $0.030,0.057$ & $0.039,0.097$ & $0.067,0.121$ & $0.046,0.132$ & $0.092,0.274$ & $0.062,0.169$ \\
\hline $\begin{array}{l}R^{a}, R_{\mathrm{W}}^{b} \\
\quad \text { (all data) }\end{array}$ & $0.038,0.060$ & $0.042,0.099$ & $0.119,0.138$ & $0.050,0.136$ & $0.118,0.296$ & $0.109,0.194$ \\
\hline
\end{tabular}

${ }^{a} R=\sum|| F_{\mathrm{o}}|-| F_{\mathrm{c}}|| / \sum\left|F_{\mathrm{o}}\right| \cdot{ }^{b} \mathrm{wR} 2=\left\{\left[\sum w\left(F_{\mathrm{o}}{ }^{2}-F_{\mathrm{c}}{ }^{2}\right)^{2}\right] / \sum\left[w\left(F_{\mathrm{o}}{ }^{2}\right)^{2}\right]\right\}^{1 / 2}$.

weeks in an $\sim 62 \%$ yield. FTIR $(\mathrm{KBr}): v_{\mathrm{NH}}=3290 \mathrm{~cm}^{-1}$ and $v_{\mathrm{C}=\mathrm{O}}$ $=1660 \mathrm{~cm}^{-1}$. Anal. Calcd for $\mathrm{C}_{21} \mathrm{H}_{21} \mathrm{CdN}_{8} \mathrm{O}_{9}$ : C, 39.30; H, 3.30; N, 17.46. Found: C, 38.97; H, 3.17; N, 17.80. 4: $\mathrm{HgCl}_{2}(27 \mathrm{mg}$, $0.1 \mathrm{mmol}$ ) dissolved in $7 \mathrm{~mL}$ of $\mathrm{C}_{2} \mathrm{H}_{5} \mathrm{OH}$ was carefully layered onto a DMF solution of $\mathbf{L} 2(24 \mathrm{mg}(0.1 \mathrm{mmol})$, dissolved in $7 \mathrm{~mL}$ of DMF). The colorless crystals were obtained within 10 days in an $\sim 71 \%$ yield. FTIR $(\mathrm{KBr}): v_{\mathrm{NH}}=3326 \mathrm{~cm}^{-1}$ and $v_{\mathrm{C}=\mathrm{O}}=1635$ $\mathrm{cm}^{-1}$. Anal. Calcd for $\mathrm{C}_{6.5} \mathrm{H}_{7} \mathrm{ClHg}_{0.5} \mathrm{~N}_{2} \mathrm{O}_{0.5}: \mathrm{C}, 30.39 ; \mathrm{H}, 2.75 ; \mathrm{N}$, 10.90. Found: C, 29.92; H, 2.84; N, 10.92. 5: $\mathrm{CuCl}_{2} \cdot 2 \mathrm{H}_{2} \mathrm{O}(17$ $\mathrm{mg}, 0.1 \mathrm{mmol}$ ) dissolved in $7 \mathrm{~mL}$ of $\mathrm{CH}_{3} \mathrm{OH}$ was carefully layered onto a dimethyl sulfoxide (DMSO) solution of L2 (27 mg (0.1 mmol), dissolved in $7 \mathrm{~mL}$ of DMSO). The pale-blue crystals were obtained within 3 weeks in an $\sim 64 \%$ yield. FTIR $(\mathrm{KBr}): v_{\mathrm{NH}}=$ $3238 \mathrm{~cm}^{-1}$ and $v_{\mathrm{C}=\mathrm{O}}=1667 \mathrm{~cm}^{-1}$. Anal. Calcd for $\mathrm{C}_{14} \mathrm{H}_{14} \mathrm{Cl}_{2^{-}}$ $\mathrm{CuN}_{4} \mathrm{O}_{2}$ : C, 41.55; H, 3.49; N, 13.84. Found: C, 41.92; H, 3.84; N, 13.92 .

Synthesis of $[\mathbf{P d}(\mathbf{P P y})(\mathbf{L 2})]\left(\mathrm{ClO}_{4}\right)_{2}(\mathbf{6})$. The reaction of $\mathbf{L 2}(27$ $\mathrm{mg}(0.1 \mathrm{mmol})$, dissolved in $\left.\mathrm{CH}_{2} \mathrm{Cl}_{2} / \mathrm{MeOH}(1: 1,25 \mathrm{~mL})\right)$ with $[\mathrm{Pd}(\mathrm{PPy})(\mathrm{OAc})]_{2}(85 \mathrm{mg}, 0.1 \mathrm{mmol})$ at room temperature for $24 \mathrm{~h}$ gave a colorless solution. The solution was filtered off, and the filtrate was concentrated to $\sim 5 \mathrm{~mL}$. Addition of excess $\mathrm{LiClO}_{4}$ yielded a pale-yellow solid. Recrystallization of the crude product by diffusion of diethyl ether into a DMF solution afforded colorless crystals with a $75 \%$ yield. ${ }^{1} \mathrm{H}$ NMR $\left(400 \mathrm{MHz}, \mathrm{CD}_{3} \mathrm{C}(\mathrm{O}) \mathrm{CD}_{3}, 25\right.$ $\left.{ }^{\circ} \mathrm{C}\right): \delta(\mathrm{ppm}) 9.15\left(\mathrm{t}, 4 \mathrm{H},{ }^{3} J_{\mathrm{HH}}=5.7 \mathrm{~Hz}\right), 8.15\left(\mathrm{~d}, 2 \mathrm{H},{ }^{3} J_{\mathrm{HH}}=4.0\right.$ $\mathrm{Hz}), 7.78\left(\mathrm{~d}, 1 \mathrm{H},{ }^{3} J_{\mathrm{HH}}=7.4 \mathrm{~Hz}\right), 7.66\left(\mathrm{~d}, 5 \mathrm{H},{ }^{3} J_{\mathrm{HH}}=5.7 \mathrm{~Hz}\right)$, $7.29\left(\mathrm{dd}, 1 \mathrm{H},{ }^{3} J_{\mathrm{HH}}=4.6 \mathrm{~Hz}\right), 7.19\left(\mathrm{t}, 1 \mathrm{H},{ }^{3} J_{\mathrm{HH}}=7.7 \mathrm{~Hz}\right), 6.97(\mathrm{t}$, $\left.1 \mathrm{H},{ }^{3} J_{\mathrm{HH}}=7.4 \mathrm{~Hz}\right), 6.09\left(\mathrm{~d}, 1 \mathrm{H},{ }^{3} J_{\mathrm{HH}}=7.8 \mathrm{~Hz}\right), 4.71(\mathrm{dd}, 4 \mathrm{H}$, $\left.{ }^{3} J_{\mathrm{HH}}=5.5 \mathrm{~Hz}\right)$. FTIR: $v_{\mathrm{NH}}=3292 \mathrm{~cm}^{-1}, v_{\mathrm{C}=\mathrm{O}}=1660 \mathrm{~cm}^{-1}$, $v_{\mathrm{Cl}-\mathrm{O}}=1095 \mathrm{~cm}^{-1}$. ESI-MS: $\left[\mathrm{M}-2 \times \mathrm{ClO}_{4}+\mathrm{H}_{2} \mathrm{O}\right]$, m/e $=$ 538, 20\%. Anal. Calcd for $\mathrm{C}_{50} \mathrm{H}_{44} \mathrm{Cl}_{2} \mathrm{~N}_{10} \mathrm{O}_{12} \mathrm{Pd}_{2}$ : C, 49.59; H, 3.66; N, 11.57. Found: C, 49.87; H, 3.49; N, 11.28.

X-ray Crystallography. Suitable crystals were mounted on glass capillaries. Data collection was carried out on a Bruker SMART

188 Inorganic Chemistry, Vol. 46, No. 1, 2007 
Table 2. Selected Bond Distances ( $\AA$ ) and Angles (deg) of 1-6

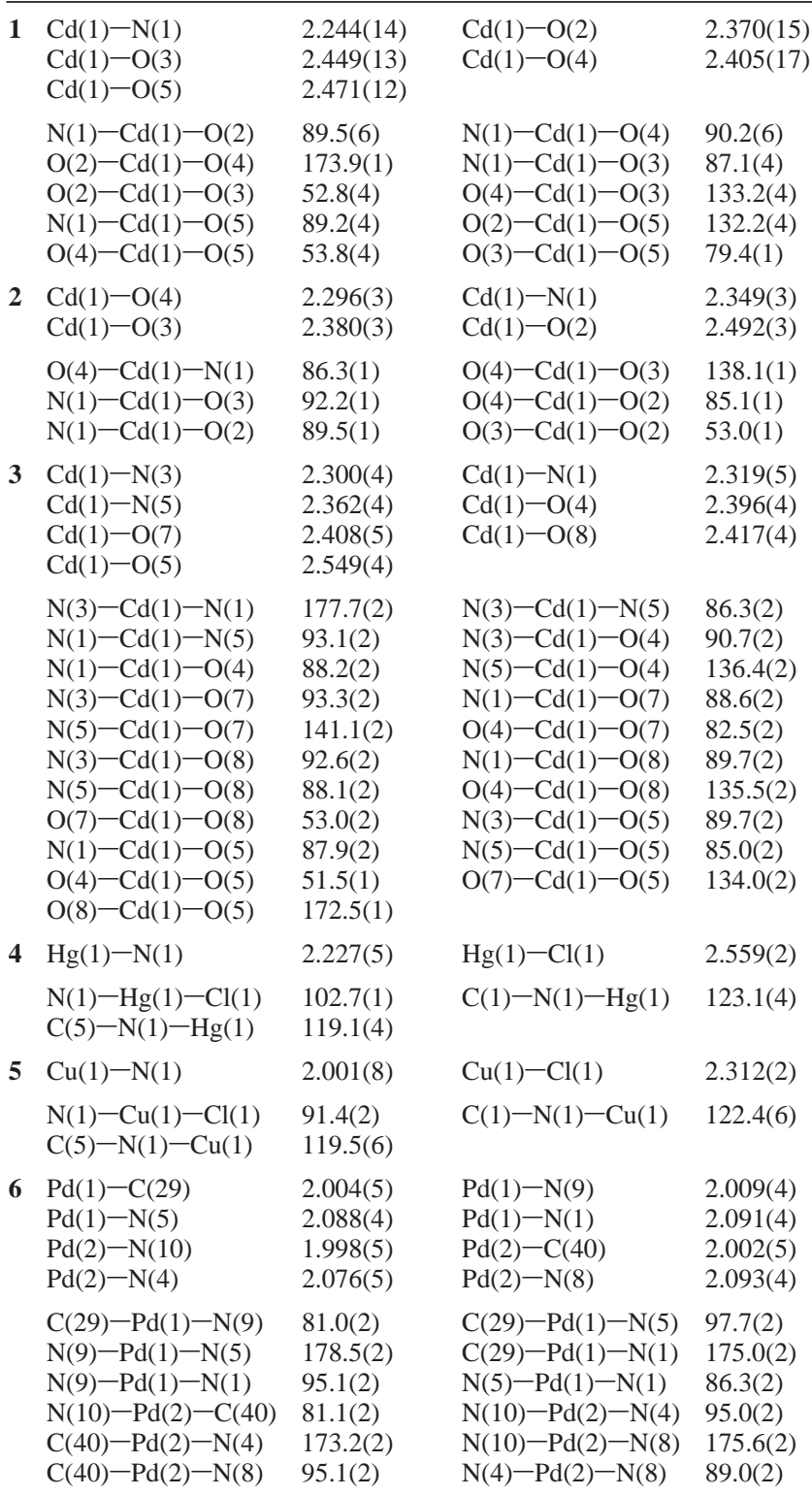

engineering studies, and indeed their applications based on the combination of the coordinative-bond approach and hydrogen bonding have recently been demonstrated. In this regard, the amide-amide hydrogen bonding has been successfully used to increase the supramolecular complexity of the dinuclear Pt(IV) $)^{10}$ complex and the $\mathrm{Zn}(\mathrm{II})^{9 \mathrm{a}}$ rectangle with $N, N^{\prime}$-bis-4-methylpyridyl oxalamide. In the dinuclear Pt(IV) complex, two 4-methyl-benzoic acid ligands trans to each other both coordinate to two different Pt(IV) centers, and the $N, N^{\prime}$-bis-4-methylpyridyl oxalamide ligand acts as a bridge between two octahedral Pt(IV) centers, leading to a 1-D chain through hydrogen bonding between two 4-methylbenzoic acid ligands and further a double-helical structure through amide-amide hydrogen bonding. For the dinuclear $\mathrm{Zn}$ (II) complex, two tetrahedral $\mathrm{Zn}$ (II) centers coordinate to two bridging $N, N^{\prime}$-bis-4-methylpyridyl oxalamide ligands and two iodo atoms to form a rectangle, and further an interesting nanotube framework was built from $\pi^{\cdots \cdots} \pi$ interactions in combination with amide-amide hydrogen bonding. In this
Table 3. Hydrogen Bonds in the Structures of 1-6

\begin{tabular}{|c|c|c|c|c|c|}
\hline complex & $\mathrm{D}-\mathrm{H} \cdots \mathrm{A}$ & $\begin{array}{c}\mathrm{D}-\mathrm{H} \\
(\AA)^{l}\end{array}$ & $\begin{array}{c}\mathrm{H} \cdots \mathrm{A} \\
(\AA)\end{array}$ & $\begin{array}{c}\mathrm{D} \cdots \mathrm{A} \\
(\AA)\end{array}$ & $\begin{array}{c}\mathrm{D}-\mathrm{H} \cdots \mathrm{A} \\
(\mathrm{deg})\end{array}$ \\
\hline 1 & $\begin{array}{l}\mathrm{N}(2)-\mathrm{H}(2 \mathrm{~A}) \cdots \mathrm{O}(3)^{a} \\
\mathrm{~N}(3)-\mathrm{H}(3 \mathrm{~A}) \cdots \mathrm{O}(5)\end{array}$ & $\begin{array}{l}0.86 \\
0.86\end{array}$ & $\begin{array}{l}2.058 \\
2.027\end{array}$ & $\begin{array}{l}2.889(18) \\
2.874(17)\end{array}$ & $\begin{array}{l}162.4 \\
167.9\end{array}$ \\
\hline 2 & $\begin{array}{l}\mathrm{N}(2)-\mathrm{H}(2 \mathrm{~A}) \cdots \mathrm{O}(5)^{b} \\
\mathrm{~N}(3)-\mathrm{H}(3 \mathrm{~A}) \cdots \mathrm{O}(3)^{c}\end{array}$ & $\begin{array}{l}0.86 \\
0.86\end{array}$ & $\begin{array}{l}2.255 \\
2.098\end{array}$ & $\begin{array}{l}2.993(14) \\
2.887(13)\end{array}$ & $\begin{array}{l}143.9 \\
152.3\end{array}$ \\
\hline 3 & $\begin{array}{l}\mathrm{N}(2)-\mathrm{H}(2 \mathrm{~B}) \cdots \mathrm{O}(3)^{d} \\
\mathrm{~N}(4)-\mathrm{H}(4 \mathrm{~A}) \cdots \mathrm{O}(5)^{e}\end{array}$ & $\begin{array}{l}0.86 \\
0.86\end{array}$ & $\begin{array}{l}2.355 \\
2.541\end{array}$ & $\begin{array}{l}3.007(6) \\
3.289(6)\end{array}$ & $\begin{array}{l}132.9 \\
146.0\end{array}$ \\
\hline 4 & $\mathrm{~N}(2)-\mathrm{H}(1 \mathrm{~A}) \cdots \cdot \mathrm{O}(1)^{f}$ & 0.78 & 2.050 & $2.782(7)$ & 157.0 \\
\hline 5 & $\begin{array}{l}\mathrm{N}(2)-\mathrm{H}(2 \mathrm{~A}) \cdots \mathrm{Cl}(1)^{g} \\
\mathrm{C}(9)-\mathrm{H}(9 \mathrm{~A}) \cdots \mathrm{N}(2)\end{array}$ & $\begin{array}{l}0.88 \\
0.99\end{array}$ & $\begin{array}{l}2.411 \\
2.354\end{array}$ & $\begin{array}{l}3.261(9) \\
3.270(20)\end{array}$ & $\begin{array}{l}162.8 \\
153.3\end{array}$ \\
\hline 6 & $\begin{array}{l}\mathrm{N}(7)-\mathrm{H}(7) \cdots \mathrm{O}(3)^{h} \\
\mathrm{~N}(6)-\mathrm{H}(6) \cdots \mathrm{O}(4)^{i} \\
\mathrm{~N}(2)-\mathrm{H}(2 \mathrm{~A}) \cdots \mathrm{O}(4)^{j} \\
\mathrm{~N}(3)-\mathrm{H}(3 \mathrm{~A}) \cdots \mathrm{O}(6)^{k} \\
\mathrm{C}(5)-\mathrm{H}(5 \mathrm{~A}) \cdots \mathrm{O}(5) \\
\mathrm{C}(24)-\mathrm{H}(24 \mathrm{~A}) \cdots \mathrm{O}(8)\end{array}$ & $\begin{array}{l}0.88 \\
0.8 \\
0.88 \\
0.88 \\
0.95 \\
0.95\end{array}$ & $\begin{array}{l}2.031 \\
2.089 \\
2.144 \\
2.175 \\
2.478 \\
2.352\end{array}$ & $\begin{array}{l}2.766(5) \\
2.871(5) \\
2.992(6) \\
2.962(8) \\
3.152(9) \\
3.199(8)\end{array}$ & $\begin{array}{l}140.2 \\
147.5 \\
161.7 \\
148.8 \\
127.9 \\
148.2\end{array}$ \\
\hline
\end{tabular}

${ }^{a-k}$ Symmetry positions of atoms A: (a) $1 / 2+x,-y,-1 / 2+z$; (b) $1 / 2+$ $x, 3 / 2-y, 1 / 2+z$; (c) $1 / 2+x,-1 / 2+y, z ;$ (d) $-1+x, 1 / 2-y,-1 / 2+z$; (e) $x, 3 / 2-y,{ }^{1} / 2+z$; (f) $x, 1+y, z$; (g) $x,-1-y,-1 / 2+z$; (h) $-x, 1-$ $y, 1-z$; (i) $1-x, 1-y, 1-z$; (j) $-x, 1-y, 1-z$; (k) $-1+x, y, z$. ${ }^{l}$ The hydrogen atoms of $\mathbf{1 - 3}$ and 5-6 were constrained to the ideal geometry using an appropriate riding model, and those of $\mathbf{4}$ were refined with the position. Data collection was carried out at 273(2) K for 1-4 and at $150(1) \mathrm{K}$ for $\mathbf{5}$ and $\mathbf{6}$, respectively.

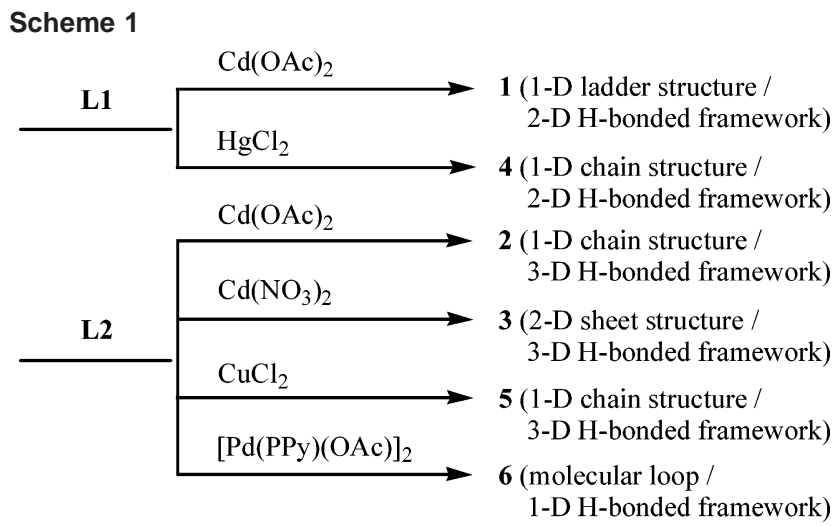

work, the crystal-engineering study was carried out by taking advantage of the different structural flexibilities of dipyridylamides (i.e., $\mathbf{L 1}$ or $\mathbf{L 2}$ ), metal salts with different anions (i.e., $\mathrm{OAc}^{-}$or $\mathrm{NO}_{3}^{-}$), metal ions with different coordination geometries (i.e., tetrahedron or square-plane), and the geometric isomerism (i.e., cis or trans coordination) to examine the effect on the assembly process and rationalize the formation of different structural frameworks.

1-6 have been isolated as air-stable solids, and their molecular structures were determined by the single-crystal $\mathrm{X}$-ray diffraction study, which confirmed the coordination polymers for $\mathbf{1 - 5}$ and a macrocyclic structure for $\mathbf{6}$. All of the complexes form extended hydrogen-bonded frameworks that are 1-D, 2-D, or 3-D in the solid state (Scheme 1). Among them, $\mathbf{1 - 5}$ are obtained by a layer method and $\mathbf{6}$ is obtained by a typical solution method with medium yields of $56-74 \%$. Three hydrogen-bonding synthons between the coordinated anions and amide groups of $\mathbf{1 - 3}$ are shown in Figure 1.

1 crystallizes in the Pn space group. In the structure of $\mathbf{1}$, as shown in Figure 2a, each $\mathrm{Cd}$ (II) center achieves a seven- 
Tzeng et al.<smiles>CC1OC2(O1)OC(C)O2</smiles>

I (1)<smiles></smiles>

II (2)<smiles></smiles>

III (3)

Figure 1. Three hydrogen-bonding synthons between the coordinated anions and the amide groups of $\mathbf{1}-\mathbf{3}$.

a
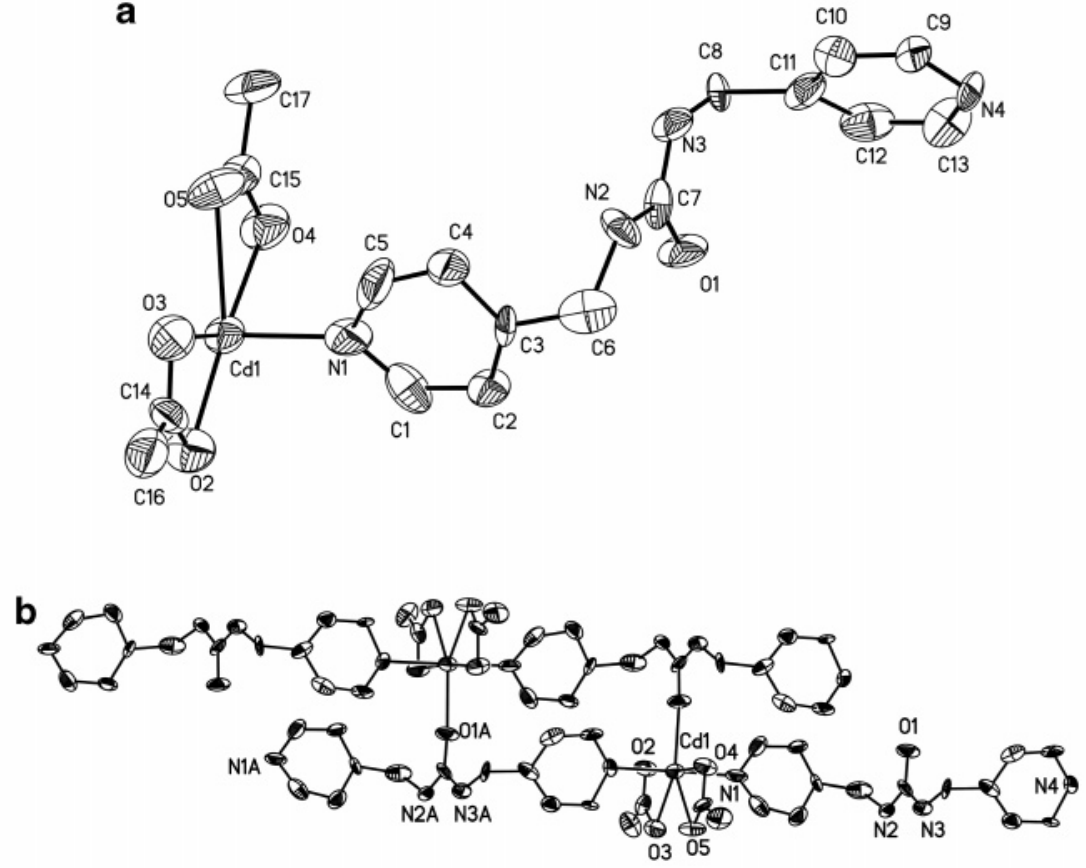

c
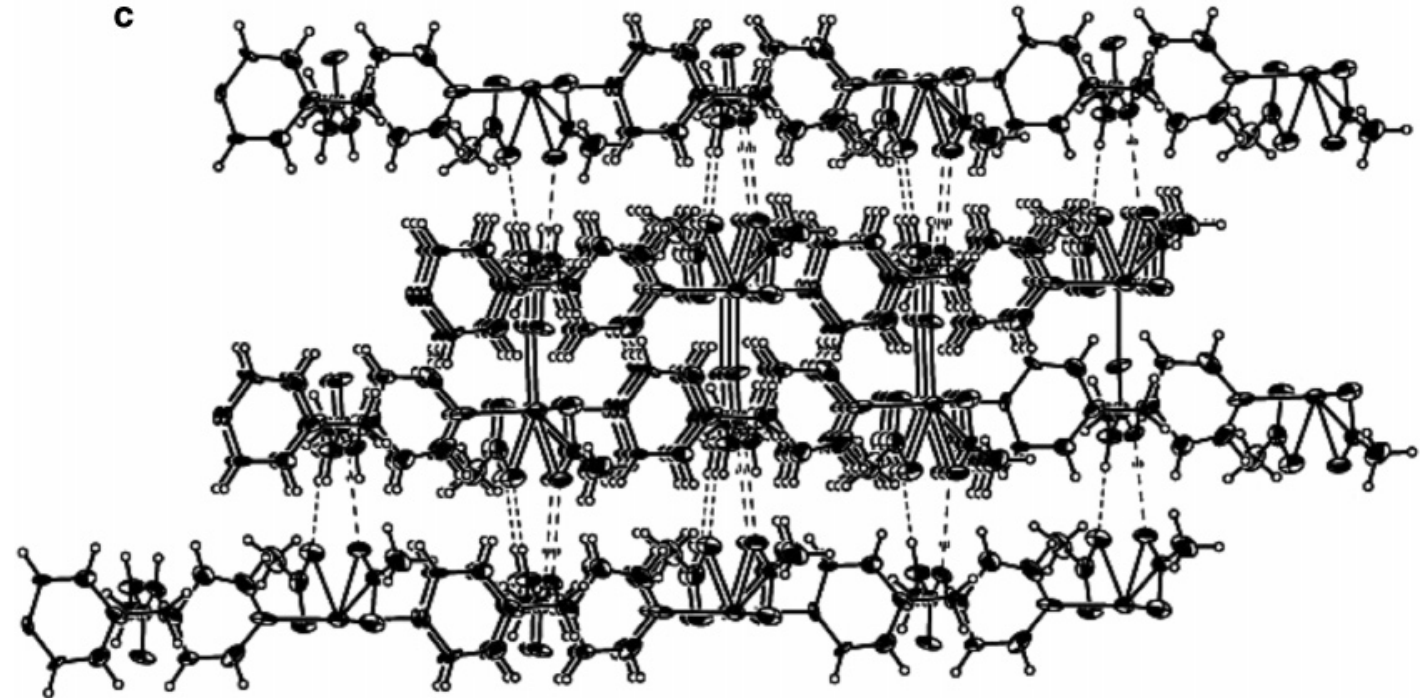

Figure 2. (a) Molecular structure (the ORTEP diagram shows 50\% probability ellipsoids), (b) 1-D ladder structure, and (c) 2-D hydrogen-bonded framework of 1 .

coordinate geometry by three independent $\mathbf{L} \mathbf{1}$ ligands and

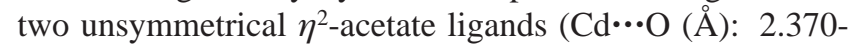
(15), 2.449(13), 2.405(17), 2.471(12)), where two pyridyl groups from two different L1 ligands and a carbonyl group from a urea form the third one-coordinate to the $\mathrm{Cd}(\mathrm{II})$ center. The structure can be first regarded as a 1-D chain through coordination to two different $\mathbf{L} \mathbf{1}$ ligands and two acetate ligands, and then the axial coordination to one urea's carbonyl group of the third L1 ligand leads $\mathbf{1}$ to give "a dimer of 1-D chains" (Figure 2b), which features a 1-D assembly of $\mathrm{Cd}_{2}(\mathbf{L} \mathbf{1})_{2}$ rectangles or a 1-D ladder chain. The distance separating the two $\mathrm{Cd}(\mathrm{II})$ centers located at the vertexes of 


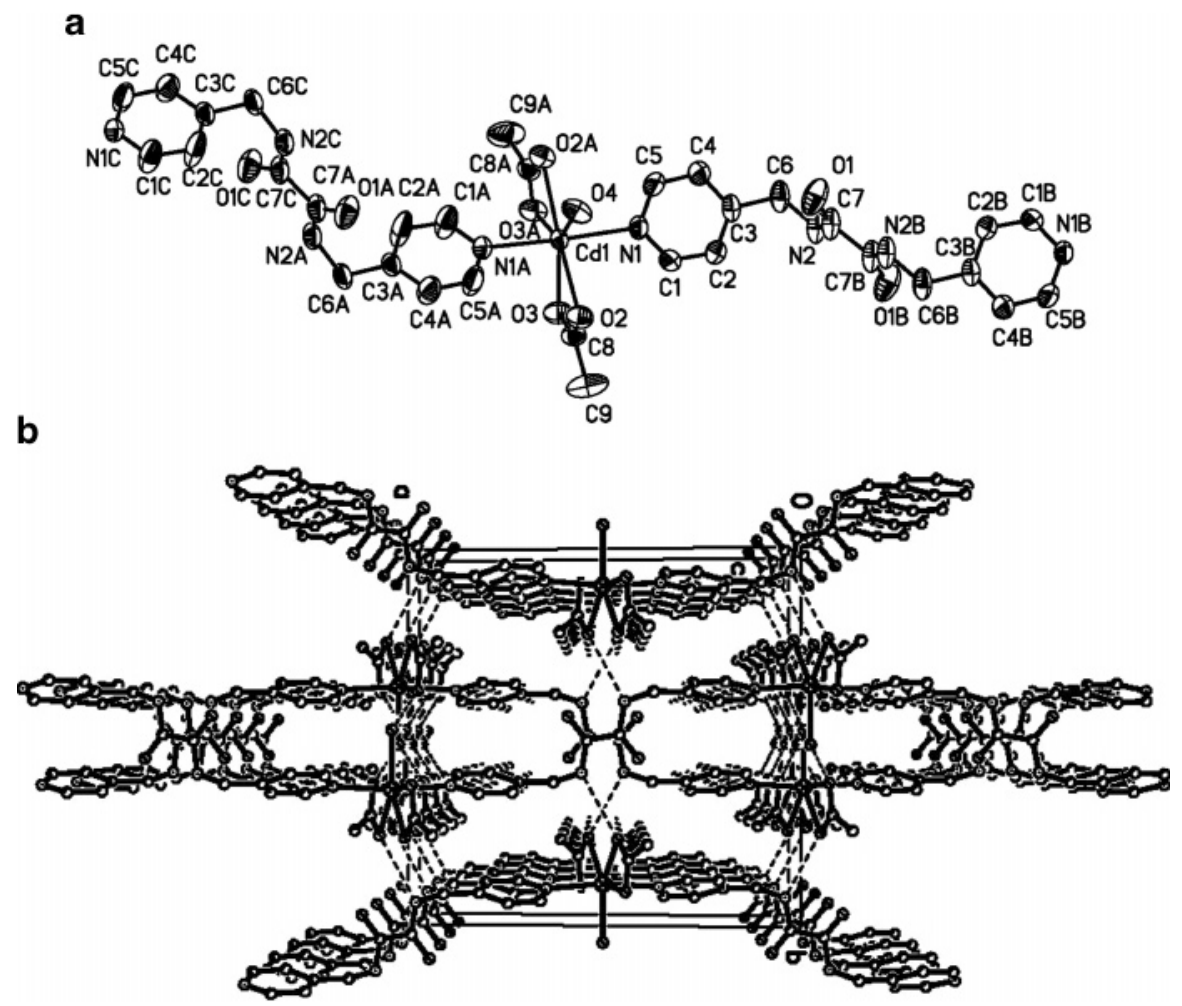

Figure 3. (a) Molecular structure (the ORTEP diagram shows 50\% probability ellipsoids) and (b) 3-D hydrogen-bonded framework of 2.

each metallamacrocycle is $\sim 8.27 \AA$, while the distances between each $\mathrm{Cd}(\mathrm{II})$ center and the carbon atoms of the two urea groups located at the two other vertexes of the rectangles are $\sim 3.54$ and $7.62 \AA$ for the long and short sides, respectively. Another notable feature of this assembly is that the 1-D chains of the rectangles interact with each other via hydrogen bonds (Figure 2c). The urea groups act as hydrogen bond donors, establishing bridges with oxygen atoms of

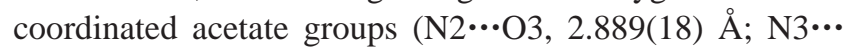
O5, 2.874(17) $\AA$ ) instead of amide-amide hydrogen bonding and generating a 2-D hydrogen-bonded structure. Significantly, this structural pattern seems to receive the benefit from the $\pi^{\cdots \cdots} \pi$ interaction between the pyridyl rings of each neighboring $\mathbf{L 1}$ pair (the edge-to-edge distance is $\sim 3.4 \AA$ ), and thus it may facilitate coordination to the $\mathrm{Cd}(\mathrm{II})$ center from the urea's carbonyl group of the third L1 ligand. Although the structural motif has been observed in $[\mathrm{Cu}-$ $\left.(\mathrm{OAc})_{2}(\mathbf{L 1})\right]_{n}{ }^{13 \mathrm{a}}$ with the weak $\mathrm{Cu} \cdots \mathrm{O}$ interaction [2.316(15) $\AA$ ] between the square-planar $\mathrm{Cu}$ (II) center and the third $\mathbf{L 1}$ ligand, where a 1-D assembly of $\mathrm{Cu}_{2}(\mathbf{L} \mathbf{1})_{2}$ rectangles is also constructed, the seven-coordinate $\mathrm{Cd}(\mathrm{II})$ center with the real $\mathrm{Cd}-\mathrm{O}$ bond $(2.372(13) \AA)$ giving rise to a similar structural motif seems more convincing in the formation of "a dimer of 1-D chains".

(13) (a) Díaz, P.; Benet-Buchholz, J.; Vilar, R.; White, A. J. P. Inorg. Chem. 2006, 45, 1617. (b) Zhang, X.; Zhou, X.; Li, D. Cryst. Growth. Des. 2006, 6, 1440. (c) Springsteen, C H.; Sweeder, R. D.; LaDuca, R. L. Cryst. Growth. Des. 2006, 6, 2308. (d) Wang, R.; Yuan, D.; Jiang, F.; Han, L.; Gong, Y.; Hong, M. Cryst. Growth. Des. 2006, 6, 1351. (e) Kong, L.-Y.; Zhu, H.-F.; Huang, Y.-Q.; Okamura, T.-a.; Lu, X.H.; Song, Y.; Liu, G.-X.; Sun, W.-Y.; Ueyama, N. Inorg. Chem. 2006, 45, 8098 .
The reaction of $\mathrm{Cd}(\mathrm{OAc})_{2}$ with $\mathbf{L} \mathbf{2}$ instead of $\mathbf{L} \mathbf{1}$ gives $\mathbf{2}$, which crystallizes in the $C 2 / c$ space group. In the structure of $\mathbf{2}$, as shown in Figure 3a, each Cd(II) center achieves a seven-coordinate geometry by two independent $\mathbf{L} 2$ ligands, two unsymmetrical $\eta^{2}$-acetate ligands $(\mathrm{Cd} \cdots \mathrm{O}(\AA)$ : 2.492 (3), 2.380(3)), and one water molecule, leading to the formation of a 1-D chain structure. It is noted that, compared with the structure of $\mathbf{1}$, the coordinated water molecule in $\mathbf{2}$ is absent in $\mathbf{1}$; the reaction conditions are similar for both, but only $\mathbf{L} \mathbf{1}$ and $\mathbf{L} \mathbf{2}$ were used for the synthesis of $\mathbf{1}$ and $\mathbf{2}$, respectively. The hydrogen bonding between the coordinated

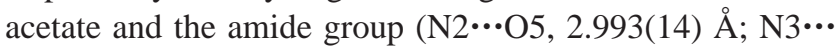
O3, 2.887(13) A), instead of amide-amide hydrogen bonding, increases the supramolecular complexity, and hence 1-D coordination polymers are further stacked into a 3-D hydrogen-bonded framework in Figure 3b. Interestingly, with a slight change in the structural flexibility from $\mathbf{L 1}$ to $\mathbf{L 2}$, different metal-organic frameworks can be generated upon reaction with the same metal salts in similar reaction conditions for $\mathbf{1}$ and $\mathbf{2}$, respectively. This result is remarkable and may be rationalized by the fact that the less structurally flexible oxalamide group, compared with the urea group, prevents the occurrence of the $\pi \cdots \pi$ interaction between the pyridyl rings of neighboring $\mathbf{L 2}$ ligands in $\mathbf{2}$ (as opposed to the case for $\mathbf{1}$ ), and hence the $\mathrm{Cd}(\mathrm{II})$ center coordinates to water instead of the urea group to achieve the sevencoordinate geometry.

The reaction of $\mathbf{L 2}$ with $\mathrm{Cd}\left(\mathrm{NO}_{3}\right)_{2}$ instead of $\mathrm{Cd}(\mathrm{OAc})_{2}$ gives 3 , which crystallizes in the $P 2_{1} / c$ space group. In the structure of $\mathbf{3}$, as shown in Figure 4a, each Cd(II) center still achieves a seven-coordinate geometry by three inde- 
Tzeng et al.
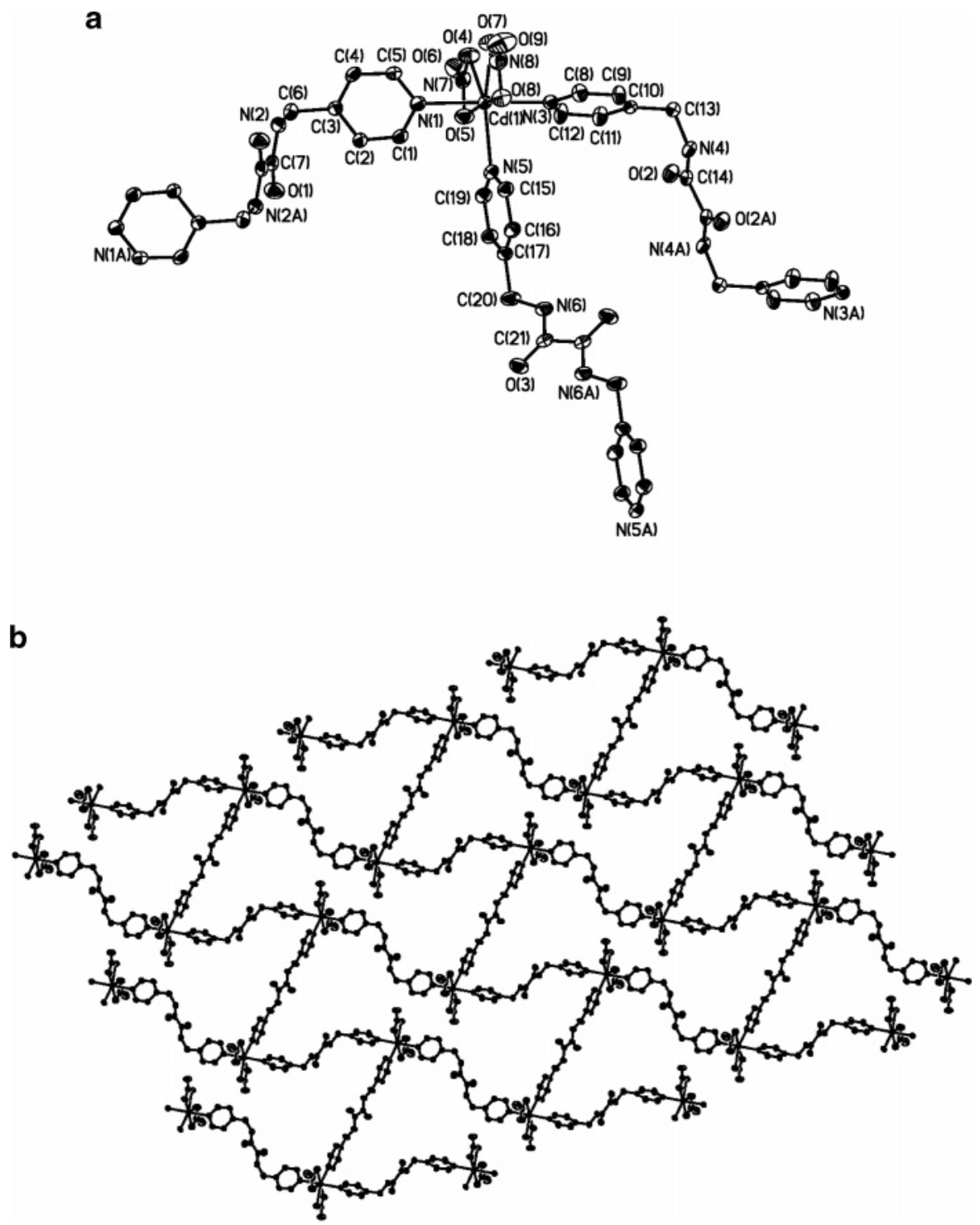

Figure 4. (a) Molecular structure (the ORTEP diagram shows 50\% probability ellipsoids) and (b) 2-D coordination polymer framework of 3.

pendent $\mathbf{L} 2$ ligands and two $\eta^{2}$-nitrate ligands (One is symmetrical, $\mathrm{Cd} \cdots \mathrm{O}(\AA): 2.408(5), 2.417(4)$. The other is unsymmetrical, $\mathrm{Cd} \cdots \mathrm{O}(\AA): 2.396(4), 2.549(4))$. Although the reaction conditions are similar for the reaction of $\mathrm{Cd}$ $\left(\mathrm{NO}_{3}\right)_{2}$ or $\mathrm{Cd}(\mathrm{OAc})_{2}$ with $\mathbf{L} \mathbf{2}$, the coordinated water molecule in $\mathbf{3}$ is absent and instead the third $\mathbf{L} \mathbf{2}$ ligand through pyridyl coordination to the $\mathrm{Cd}(\mathrm{II})$ center is observed, with a 2-D coordination polymer formed. Significantly, the interesting 90-membered rings constructed from six seven-coordinate $\mathrm{Cd}(\mathrm{II})$ centers as connectors and the six $\mathbf{L} 2$ ligands propagate into a 2-D sheet structure in Figure 4b, and every neighboring two sheets are hydrogen-bonded and interpenetrated together between the coordinated nitrate and the amide group (N4. ..O5, 3.289(6) ̊̊), leading to a sheet pair. In addition, every sheet pair is further hydrogen-bonded to stack into a 3-D framework through amide-amide hydrogen bonding (N2 * -O3, 3.007(6) $\AA$ ). It is noted that, with a change in $\mathrm{Cd}(\mathrm{II})$ salt anions used $\left(\mathrm{OAc}^{-}\right.$or $\left.\mathrm{NO}_{3}{ }^{-}\right)$, two dramatic and different metal-organic frameworks of $\mathbf{2}$ and $\mathbf{3}$ can be obtained upon the reaction with $\mathbf{L} \mathbf{2}$ in similar reaction conditions. However, the bond angles of $\mathrm{O}(2)-\mathrm{Cd}(1)-\mathrm{O}(2 \mathrm{~A})\left(170.3^{\circ}\right)$ in $2\left(\mathrm{OAc}^{-}\right)$ and of $\mathrm{O}(5)-\mathrm{Cd}(1)-\mathrm{O}(8)\left(172.5^{\circ}\right)$ in $3\left(\mathrm{NO}_{3}{ }^{-}\right)$are comparable, and the reason why the coordination environments for 2 (two $\mathbf{L} 2$ ligands, two $\mathrm{OAc}^{-}$anions, and one water) and $\mathbf{3}$ (three $\mathbf{L} 2$ ligands and two $\mathrm{NO}_{3}{ }^{-}$anions) are different is still unclear. In fact, the anion-directed assembly is an interesting phenomenon in crystal-engineering studies and has been reported by several groups. ${ }^{13}$

While $\mathbf{1}-\mathbf{3}$ contain seven-coordinate $\mathrm{Cd}(\mathrm{II})$ centers, $\mathbf{4}$ and 5, with their respective space groups being $P 2 / n$ and $C 2 / c$, contain four-coordinate tetrahedral and square-planar metal centers, respectively. In the structure of $\mathbf{4}$, as shown in Figure $5 \mathrm{a}$, each $\mathrm{Hg}(\mathrm{II})$ center is coordinated by two independent L1 ligands and two $\mathrm{Cl}$ ligands, leading to a 1-D chain structure. A typical amide-amide hydrogen bond (N2 $\cdots \mathrm{O} 1$, 2.782(7) A) increasing the structural complexity from a 1-D chain to a 2-D herringbone-like hydrogen-bonded framework is observed in the solid state (Figure 5b). Moreover, long double $\mathrm{Hg} \cdots \mathrm{Cl}$ contacts of $3.56 \AA$ (the sum of the van der Waals radii is $3.30 \AA$ ) are also suggested to contribute, in part, to the formation of these hydrogen-bonded frameworks. In the structure of $\mathbf{5}$, as shown in Figure $6 \mathrm{a}$, each square- 

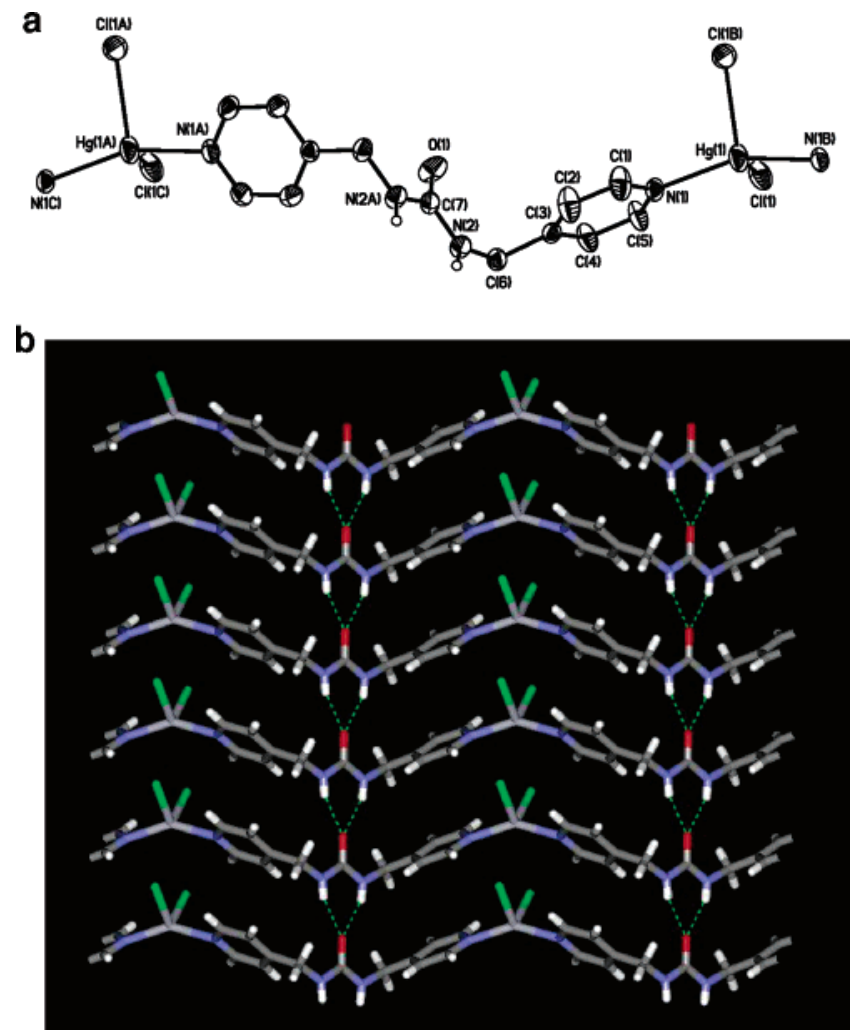

Figure 5. (a) Molecular structure (the ORTEP diagram shows $50 \%$ probability ellipsoids) and (b) 2-D hydrogen-bonded framework of 4 .

planar $\mathrm{Cu}(\mathrm{II})$ center is coordinated by two independent $\mathbf{L} \mathbf{2}$ ligands and two $\mathrm{Cl}$ ligands with a trans configuration, giving rise to the formation of a 1-D chain structure similar to that of 4. In addition, the $\mathrm{Cu}$ (II) center also shows weak interactions $(2.55 \AA)$ with the urea's carbonyl groups from the neighboring $\mathbf{L} \mathbf{2}$ ligands in axial positions, which can be considered as a Jahn-Teller effect, a common coordination behavior in $\mathrm{d}^{9}$-metal complexes (especially $\mathrm{Cu}$ (II) centers). Hydrogen-bonding interactions between $\mathrm{Cl}$ and amide groups $(\mathrm{N} 2 \cdots \mathrm{Cl} 1,3.261(9) \AA)$, nonclassical $\mathrm{CH} \cdots \mathrm{N}(\mathrm{C} \cdots \mathrm{N}, 3.270-$ (20) $\AA$ ) interactions, and weak $\mathrm{Cu} \cdots \mathrm{O}$ interactions in $\mathbf{5}$ are thus expected cooperatively to contribute to the formation of the hydrogen-bonded framework (its 2-D and 3-D frameworks are shown in Figure $6 \mathrm{~b}$ and $\mathrm{c}$, respectively). Besides, there are two disordered methanol molecules in an asymmetric unit.

Apart from $\mathbf{L} \mathbf{1}$ and $\mathbf{L} \mathbf{2}$ as components for the coordination polymers of $\mathbf{1 - 5 , ~} \mathbf{L 2}$ is also successfully used to construct supramolecular entities in this study. To date, only a handful of macrocyclic examples containing pyridyl-amides as bridging ligands have been reported. ${ }^{3 \mathrm{~h}, 8,9 \mathrm{a}, 14} \mathbf{6}$ crystallizes in the $P 1$ space group, where the $\mathrm{Pd}(\mathrm{II})$ center adopts a squareplanar geometry and its molecular structure features an interesting molecular loop, bearing a cyclometallated ligand (PPy) and two L2 ligands as the bridging ligands in Figure

(14) (a) Baer, A. J.; Koivisto, B. D.; Côté, A. P.; Taylor, N. J.; Hanan, G. S.; Nierengarten, H.; Dorsselaer, A. V. Inorg. Chem. 2002, 41, 4987. (b) Park, Y. J.; Kim, J.-S.; Youm, K.-T.; Lee, N.-K.; Ko, J.; Park, H.-S.; Jun, M.-J. Angew. Chem., Int. Ed. 2006, 45, 4290. (c) Yue, N L. S.; Eisler, D. J.; Jennings, M. C.; Puddephatt, R. J. Inorg. Chem. 2004, 43, 7671. (d) Yue, N. L. S.; Qin, Z.; Jennings, M. C.; Eisler, D. J.; Puddephatt, R. J. Inorg. Chem. Commun. 2003, 6, 1269. 7a. The average $\mathrm{Pd}-\mathrm{C}$ distance of 2.003(5) $\AA$ is longer than that of $[\mathrm{Pd}(\mathrm{PPy})(\mathrm{OAc})]_{2}(1.962(4) \AA),{ }^{15}$ but it is slightly shorter than the average Pd-N distance of 2.059(5) $\AA$ in $\mathbf{6}$. This may be explained by the steric repulsion between PPy and the pyridyl groups of $\mathbf{L} \mathbf{2}$ in the molecular loop. Surprisingly, PPy and $\mathrm{Pd}_{2}(\mathbf{L 2})_{2}$ are not coplanar, but a boat form is observed in the solid state, where each side of the boat form of 6 (pseudo-cyclohexane) ranges from 6.12 to $6.39 \AA$ A This intriguing structural motif is possibly ascribed to a syn form of $\mathbf{L} \mathbf{2}$ as well as the steric repulsion between PPy and the pyridyl groups of $\mathbf{L} \mathbf{2}$ in the structural backbone of $\operatorname{Pd}_{2}(\mathbf{L} 2)_{2}$, whereas an anti form of $\mathbf{L} \mathbf{2}$ exists in the previous examples of $\mathbf{2}, \mathbf{3}$, and $\mathbf{5}$. Actually, the syn form of $\mathbf{L} \mathbf{2}$ has been previously observed in the $\left[\mathrm{ZnI}_{2}(\mathbf{L 2})\right]_{2}$ rectangle, ${ }^{9 a}$ but its two L2 ligands are roughly coplanar. In addition, one $\mathrm{ClO}_{4}{ }^{-}$anion is encapsulated inside the cavity of the molecular loop through multiple nonclassical $\mathrm{CH} \cdot \cdots \mathrm{O}$ interactions

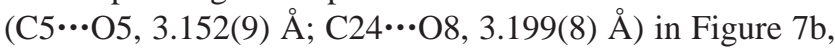
and the other one is only singly hydrogen-bonded to $\mathbf{L} 2(\mathrm{~N} 3$. ..O6, 2.962(8) A). Finally, amide-amide hydrogen bonding $(\mathrm{N} 7 \cdots \mathrm{O} 3,2.766(5) \AA ; \mathrm{N} 6 \cdots \mathrm{O} 4,2.871(5) \AA ; \mathrm{N} 2 \cdots \mathrm{O} 4,2.992-$ (6) $\AA$ ) increases the structural complexity of 6 to a 1-D hydrogen-bonded framework with a ladder pattern in Figure $7 \mathrm{c}$.

\section{Conclusions}

In the current study, the different structural flexibility of the urea group (L1), compared with the oxalamide group (L2), may be responsible for the formation of different structural frameworks from a 1-D ladder structure (1) to a 1 -D chain structure (2), where the $\pi \cdot \cdots \pi$ interaction between the pyridyl rings of each neighboring $\mathbf{L} 1$ pair facilitates the axial coordination to the $\mathrm{Cd}(\mathrm{II})$ center through one urea's carbonyl group of the third L1 ligand to give "a dimer of 1-D chains". With only the difference in the coordinated anions for $\mathbf{2}$ and $\mathbf{3}$, the structural framework could change from a 1-D (2) to a 2-D (3) coordination polymer. The delicate change for the seventh coordination from water (2) to $\mathbf{L 2}$ (3) seems to play a vital role in this structural difference, but the reason is still unclear. However, as expected, the coordinated anions for 1-3 are all involved in hydrogen bonding with amide groups, where these interactions in $\mathbf{1}$ and $\mathbf{2}$ are the only hydrogen-bonding interactions in their hydrogen-bonded frameworks. Containing a tetrahedral $\mathrm{Hg}$ (II) center, $\mathbf{4}$ forms a 1-D chain structure with a typical amide-amide hydrogen bonding of $\mathbf{L 1}$ and further a 2-D hydrogen-bonded framework through additional $\mathrm{Hg} \cdots \mathrm{Cl}$ interactions. In 5, the square-planar $\mathrm{Cu}$ (II) center coordinates to two L2 ligands in a trans conformation to form a 1-D chain structure, and the $\mathrm{Cu}$ (II) center also shows weak interactions with the urea's carbonyl groups from the neighboring $\mathbf{L} 2$ ligands in axial positions (a Jahn-Teller effect). Indeed, weak $\mathrm{Cu} \cdots \mathrm{O}$ interactions, hydrogen-bonding interactions between $\mathrm{Cl}$ and amide groups, and nonclassical $\mathrm{CH} \cdots \mathrm{N}$ interactions cooperatively contribute to the formation of this 3-D hydrogen-bonded framework. Moreover, the

(15) Unpublished results. 
Tzeng et al.

a
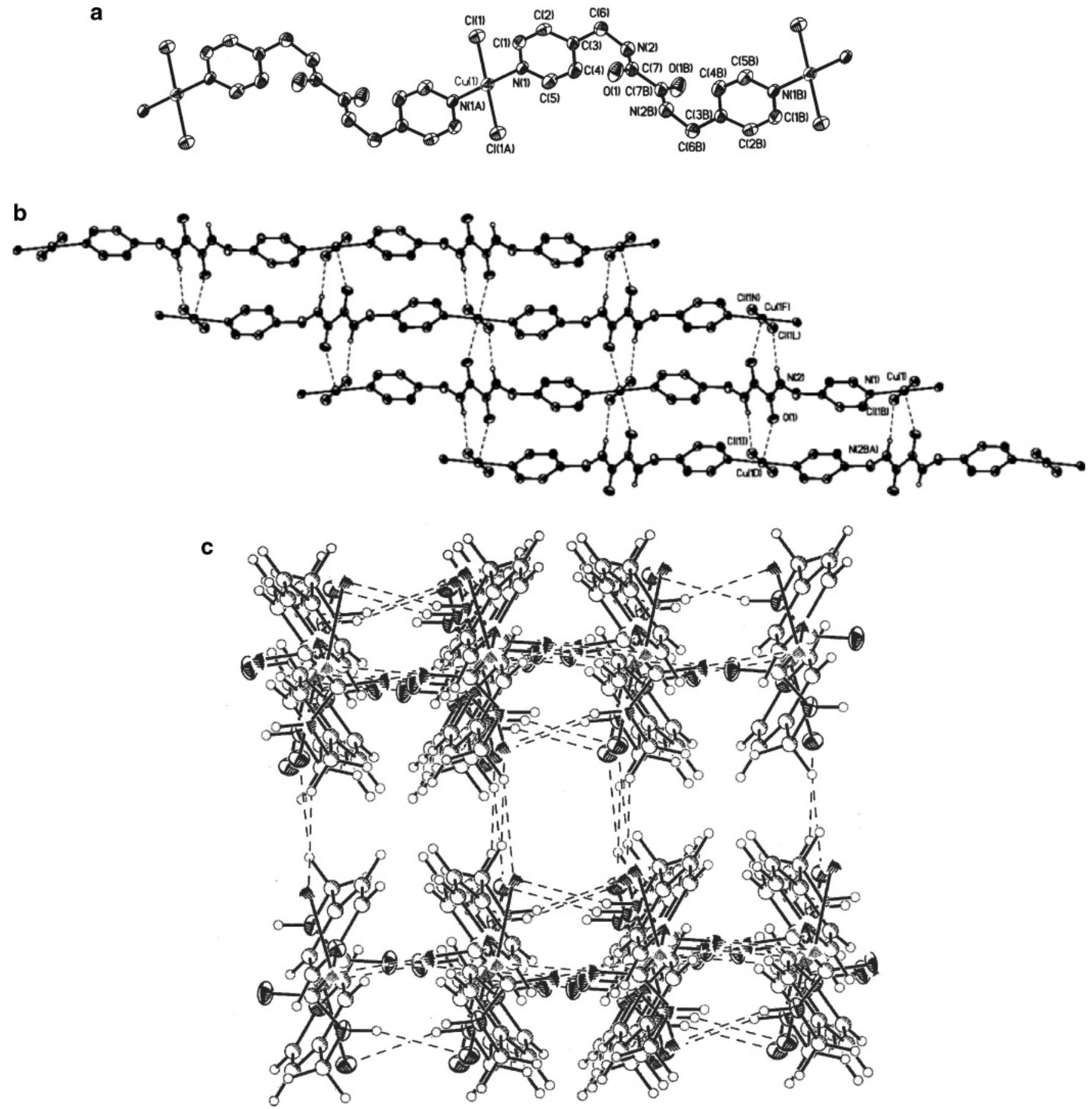

Figure 6. (a) Molecular structure (the ORTEP diagram shows 50\% probability ellipsoids) and (b) 2-D and (c) 3-D hydrogen-bonded frameworks of 5.

different structural conformation (i.e., a syn or anti conformation) also possibly shows an effect on the formation of different structural motifs (i.e., a syn form in a macrocycle or an anti form in a coordination polymer). The reaction of $[\mathrm{Pd}(\mathrm{PPy})(\mathrm{OAc})]_{2}$ with $\mathbf{L 2}$ gives rise to $\mathbf{6}$, which is an interesting molecular loop with two square-planar Pd(II) centers, bearing a cyclometalated ligand (PPy) and two L2 ligands as bridging ligands. The formation of the molecular loop (6) can be rationalized by the fact that the Pd(II) center provides two cis coordination sites bonding with two L2 ligands, where the $\mathbf{L} 2$ ligands adopt a syn form. Consequently, a boat form of $\mathbf{6}$ is obtained in the solid state to encapsulate one $\mathrm{ClO}_{4}{ }^{-}$anion inside the cavity through multiple $\mathrm{CH} \cdots \mathrm{O}$ interactions, and further a 1-D hydrogenbonded framework with a ladder pattern through amideamide hydrogen bonding.

This work shows that the crystal-engineering study may be carried out by taking advantage of the different structural flexibilities of dipyridyl-amide ligands, metal salts with different anions, metal ions with different coordination geometries, and the geometric isomerism. Actually, the compounds studied here $(\mathbf{1}-\mathbf{6})$ have been confirmed to have 1-D, 2-D, and 3-D hydrogen-bonded frameworks, and thus it has been suggested that, by tuning each of the abovementioned factors, different structural motifs may be obtained. Although the assembly process of metal-containing 
a

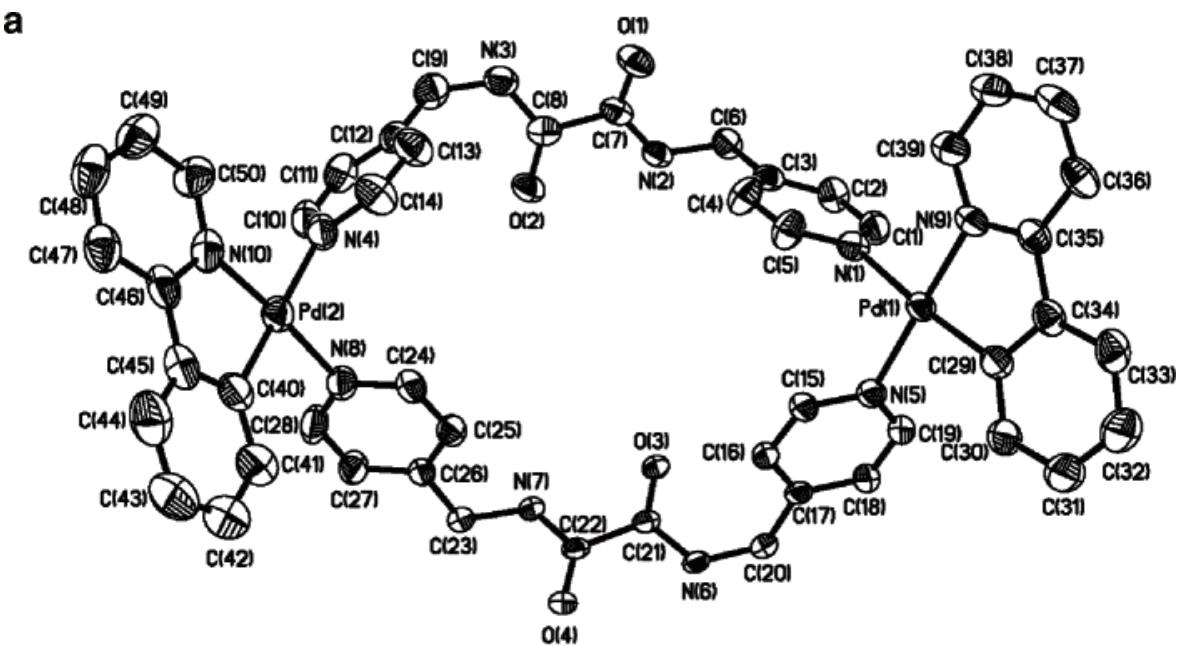

b
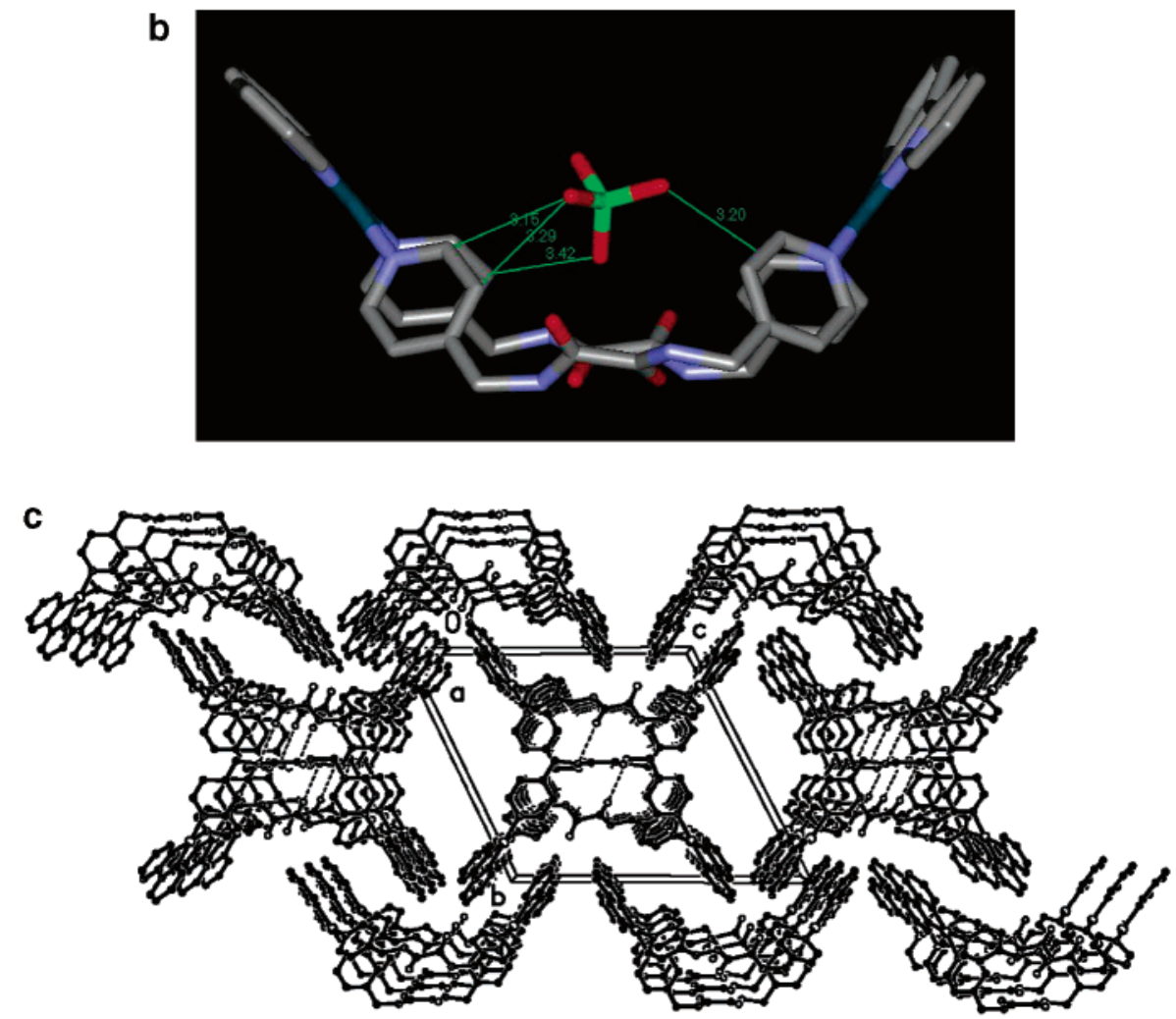

Figure 7. (a) Molecular structure of $\mathbf{6}$ (the ORTEP diagram shows $50 \%$ probability ellipsoids); (b) the boat structure of 6 with an entrapped $\mathrm{ClO}_{4}{ }^{-}$anion inside the cavity through multiple $\mathrm{CH}^{\cdots} \cdot \mathrm{O}$ interactions; and (c) the 1-D hydrogen-bonded framework of 6.

dipyridyl-amides cannot be totally understood at this moment, useful applications based on the combination of the coordinative-bond approach and hydrogen-bonding interactions contributing to crystal-engineering studies in a systematic way have been well demonstrated. In addition, the dipyridylamide system with amides incorporated into spacers as functional units and channels in the solid state could make this interesting family of dipyridyl-amides promising candidates for crystal-engineering (i.e., construction of porous materials or cages) and molecular-recognition studies (i.e., sensors for anions or volatile organic compounds). In this context, understanding the basic principle of the assembly process may pave a new way to construct new supramolecular functional materials.

Acknowledgment. We thank the National Science Council and National Chung Cheng University of the Republic of China for financial support.

Supporting Information Available: CIF files for 1-6. This material is available free of charge via the Internet at http:// pubs.acs.org.

IC061528T 